\title{
Uji Perlakuan Kompos Daun Jagung (Zea mays) dan Pupuk NPK Phonska Terhadap Tinggi Tanaman dan Hasil Kacang Tanah (Arachis hypogaea L.)
}

\section{Test of Corn Leaves (Zea mays) Compost and NPK Phonska Fertilizer on Plant Height and Peanut (Arachis hypogaea L.) Results}

\author{
Randy Kriswanto ${ }^{1}$, Mahdalena $^{2}$, \\ 1 Alumni Program Studi Agroteknologi, Fakultas Pertanian, Universitas Widya Gama Mahakam Jl. KH. Wahid \\ Hasyim, Sempaja, Samarinda, Kalimantan Timur, Indonesia \\ 2 Tenaga Pendidik Program Studi Agroteknologi, Fakultas Pertanian, Universitas Widya Gama Mahakam Jl. \\ KH. Wahid Hasyim, Sempaja, Samarinda, Kalimantan Timur, Indonesia
}

Diterima : 6 September 2019 Disetujui : 31 Desember 2019

Email : randykriswanto7@gmail.com, mahda.amin@yahoo.com

\begin{abstract}
Test of Corn Leaves (Zea mays) Compost and NPK Phonska Fertilizer on Plant Height and Peanut Yield (Arachis hypogaea L.). This study aims to determine the effect of giving corn leaf compost fertilizer and NPK phonska fertilizer and its interactions on the growth and yield of peanuts. The study used a Randomized Block Design with a $4 x 4$ experiment with 2 factorial replications 3 times. The first factor is the dose of compost of corn leaf compost consisting of 4 levels, namely: o0 (control), o1 (100 g / plant), o2 (200 g / plant), o3 (300 g / plant).

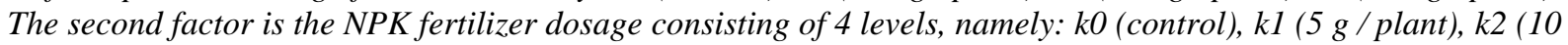
$\mathrm{g} /$ plant $), \mathrm{k} 3$ (15 g / plant). The results showed that the treatment of corn leaf compost did not have a significant effect on plant height at 30.60, and 90 days after planting, pod weight and number of pods. Phonska NPK fertilizer does not have a significant effect on plant height at 30, 60, and 90 days after planting, but it has a significant effect on the number of pods and pod weight. The interaction between the compost dose of corn leaf compost and NPK phonska had no significant effect on plant height, pod weight and number of pods.
\end{abstract}

Keywords: compost and npk phonska and peanut

\section{PENDAHULUAN}

Kacang tanah (Arachis hypogaea L.) secara ekonomi merupakan tanaman kacang-kacangan yang menduduki urutan kedua setelah kedelai, sehingga berpotensi untuk dikembangkan karena memiliki nilai ekonomi yang tinggi dan peluang pasar dalam negeri yang cukup besar. Biji kacang tanah dapat digunakan langsung untuk pangan dalam bentuk sayur, goreng, rebus, bahan baku industri seperti keju, sabun, dan minyak, serta berangkasnya untuk pakan ternak dan pupuk (Marzuki, 2007)

Hasil tanaman kacang tanah di Indonesia tergolong rendah, karena masih berada di bawah potensi produksi. Hasil kacang tanah lokal baru mencapai 1,45 ton $\mathrm{ha}^{-1}$, lebih rendah dibanding dengan potensi hasil varietas unggul seperti varietas panter dan singa yang dapat mencapai 4,5 ton ha (Adisarwanto, 2009). Hasil tanaman kacang tanah masih dapat ditingkatkan, walaupun saat ini tersedia beberapa varietas unggul namun belum banyak diketahui oleh petani dan petani lebih mudah memasarkan varietas lokal yang mempunyai bentuk biji dan polong yang disukai oleh konsumen serta mempunyai keunggulan spesifik lainnya seperti ketahanan terhadap penyakit layu (Adisarwanto, 2009).

Kompos merupakan salah satu pupuk organik yang digunakan pada pertanian untuk mengurangi pupuk anorganik. Penggunaan kompos dapat memperbaiki sifat fisik tanah dan mikrobiologi tanah (Syam, 2003). Sisa tanaman jagung apabila dibiarkan dapat menimbulkan kerugian seperti lahan menjadi kotor dan tempat bersarangnya hama/penyakit, sementara itu bila dimanfaatkan dengan baik dapat memberikan manfaat besar, limbah tanaman jagung sangat berpotensi sebagai sumber hara. Limbah jagung berupa batang dan daun merupakan sumber bahan organik yang paling ekonomis karena bahan ini sebagai hasil sampingan dari kegiatan usahatani sehingga tidak membutuhkan biaya dan areal khusus untuk pengadaannya.

Penggunaan pupuk organik memiliki kandungan unsur hara yang relatif rendah sehingga perlu disuplay dengan pupuk anorganik. Penambahan pupuk NPK pada budidaya kacang tanah dapat meningkatkan produksi pada dosis yang optimal. Hara nitrogen $(\mathrm{N})$, fosfor $(\mathrm{P})$, dan kalium (K) merupakan hara esensial bagi tanaman. Peningkatan dosis pemupukan nitrogen 
(N) di dalam tanah secara langsung dapat meningkatkan kadar protein dan produksi tanaman kacang tanah, tetapi pemenuhan unsur nitrogen $(\mathrm{N})$ saja tanpa fosfor $(\mathrm{P})$ dan kalium $(\mathrm{K})$ akan menyebabkan tanaman mudah rebah, peka terhadap serangan hama penyakit dan menurunnya kualitas produksi (Rauf dkk 2000).

Berdasarkan uraian diatas, maka perlu dilakukan penelitian untuk mengetahui pengaruh pemberian pupuk kompos daun tanaman jagung dan pupuk NPK phonska terhadap pertumbuhan dan hasil tanaman kacang tanah.

\section{BAHAN DAN METODE}

Bahan yang digunakan dalam penelitian ini adalah daun tanaman jagung, pupuk kandang ayam, gula merah, EM-4, benih kacang tanah varietas gajah, pupuk NPK Phonska, dolomite, furadan 3G, insektisida Tetrin 36ec 100 ml.Penelitian ini dilaksanakan selama 3 bulan, mulai dari tanggal 10 Mei 2018 sampai dengan tanggal 2 Juli 2018, tempat penelitian lahan petani di Jl. PM. Noor, Kelurahan Sempaja Timur, Kecamatan Samarinda Utara Kalimantan Timur. Faktor pertama adalah perlakuan pupuk kompos yang terdiri dari 4 taraf, yaitu; $\mathrm{o}_{0}=$ kontrol, $\mathrm{o}_{1}=100 \mathrm{~g} / \mathrm{polybag}, \mathrm{o}_{2}=200 \mathrm{~g} /$ polybag dan $\mathrm{O}_{3}=300 \mathrm{~g} /$ polybag. Faktor kedua adalah perlakuan pupuk NPK yang terdiri dari 4 taraf, yaitu; $\mathrm{k}_{0}=$ kontrol, $\mathrm{k}_{1}=5 \mathrm{gram} /$ tanaman, $\mathrm{k}_{2}=10$ gram/tanaman dan $\mathrm{k}_{3}=15$ gram $/$ tanaman. Pelaksanan penelitian meliputi ; persiapan daun jagung, pembuatan kompos daun jagung, analisis tanah, analisis kompos jagung, persiapan benih, persiapan lahan, pemberian pupuk kompos, penanaman, penyulaman, penjarangan, penyiangan, pembumbunan, pemberian pupuk NPK, penyiraman, pengendalian organisme penggangu tanaman (OPT), pengambilan data dan pemanenan. Data yang diambil dihitung menggunakan sidik ragam. Hasil sidik ragam menunjukkan hasil berbeda nyata maka akan dilanjutkan dengan uji BNT pada taraf $5 \%$.

\section{HASIL DAN PEMBAHASAN}

Tabel 1. Pengaruh Pemberian Pupuk Kompos Daun Jagung dan Pemberian Pupuk NPK Phonska Terhadap Rata-Rata Tinggi Tanaman, Berat Polong dan Jumlah Polong

\begin{tabular}{|c|c|c|c|c|c|}
\hline \multirow{2}{*}{ Perlakuan } & \multicolumn{3}{|c|}{ TinggiTanaman $(\mathrm{cm})$} & \multirow{2}{*}{$\begin{array}{c}\text { Berat polong }(\mathrm{g}) \\
90 \mathrm{HST}\end{array}$} & \multirow{2}{*}{$\begin{array}{c}\text { Jumlah polong (buah) } \\
90 \mathrm{HST}\end{array}$} \\
\hline & $30 \mathrm{HST}$ & $60 \mathrm{HST}$ & $90 \mathrm{HST}$ & & \\
\hline Kompos (O) & $\operatorname{tn}$ & $\operatorname{tn}$ & $\operatorname{tn}$ & $\operatorname{tn}$ & tn \\
\hline $\mathrm{O}_{0}$ & 9,86 & 38,00 & 41.08 & 67,33 & 18,50 \\
\hline $\mathrm{O}_{1}$ & 10,41 & 37,92 & 42.42 & 71,75 & 18,92 \\
\hline $\mathrm{O}_{2}$ & 9,29 & 36,17 & 40.75 & 68,00 & 18,50 \\
\hline $\mathrm{O}_{3}$ & 1022 & 35,42 & 40.33 & 63,67 & 17,92 \\
\hline NPK Phonska (K) & tn & tn & tn & $*$ & $* *$ \\
\hline $\mathrm{k}_{0}$ & 10,19 & 39,00 & 42,92 & $58,42 \mathrm{c}$ & $17,17 \mathrm{~b}$ \\
\hline $\mathrm{k}_{1}$ & 9,37 & 36,50 & 40,75 & $68,25 b$ & $18,58 \mathrm{a}$ \\
\hline $\mathrm{k}_{2}$ & 10,36 & 36,58 & 41,00 & $69,92 \mathrm{ab}$ & $18,75 \mathrm{a}$ \\
\hline $\mathrm{k}_{3}$ & 9,86 & 35,42 & 39,92 & $74,17 \mathrm{a}$ & $19,33 a$ \\
\hline Interaksi (OxK) & tn & tn & tn & tn & tn \\
\hline $\mathrm{o}_{0} \mathrm{k}_{0}$ & 9,30 & 37,00 & 41,00 & 57,33 & 17,00 \\
\hline $\mathrm{o}_{0} \mathrm{k}_{1}$ & 9,47 & 40,33 & 41,67 & 65,67 & 18,33 \\
\hline $\mathrm{o}_{0} \mathrm{k}_{2}$ & 10,67 & 38,00 & 40,33 & 72,67 & 19,33 \\
\hline $\mathrm{o}_{0} \mathrm{k}_{3}$ & 10,00 & 36,67 & 41,33 & 73,67 & 19,33 \\
\hline $\mathrm{o}_{1} \mathrm{k}_{0}$ & 10,83 & 42,00 & 45,00 & 68,00 & 18,33 \\
\hline $\mathrm{o}_{1} \mathrm{k}_{1}$ & 8,50 & 35,33 & 41,33 & 63,33 & 17,67 \\
\hline $\mathrm{o}_{1} \mathrm{k}_{2}$ & 11,47 & 38,33 & 44,67 & 74,33 & 19,33 \\
\hline $\mathrm{o}_{1} \mathrm{k}_{3}$ & 10,83 & 36,00 & 38,67 & 81,73 & 20,33 \\
\hline $\mathrm{O}_{2} \mathrm{k}_{0}$ & 10,47 & 40,33 & 43,00 & 59,67 & 17,33 \\
\hline $\mathrm{O}_{2} \mathrm{k}_{1}$ & 8,40 & 35,67 & 39,33 & 81,00 & 20,33 \\
\hline $\mathrm{O}_{2} \mathrm{k}_{2}$ & 9,97 & 33,67 & 38,33 & 64,67 & 18,00 \\
\hline $\mathrm{O}_{2} \mathrm{k}_{3}$ & 8,33 & 35,00 & 42,33 & 66,67 & 18,33 \\
\hline $\mathrm{O}_{3} \mathrm{k}_{0}$ & 10,17 & 36,67 & 42,67 & 48,67 & 16,00 \\
\hline $\mathrm{O}_{3} \mathrm{k}_{1}$ & 11,10 & 34,67 & 40,67 & 63,00 & 18,00 \\
\hline $\mathrm{O}_{3} \mathrm{k}_{2}$ & 9,33 & 36,33 & 40,67 & 68,00 & 18,33 \\
\hline $\mathrm{O}_{3} \mathrm{k}_{3}$ & 10,27 & 34,00 & 37,33 & 75,00 & 19,33 \\
\hline
\end{tabular}




\section{Pengaruh Pemberian Pupuk Kompos Jagung Terhadap Produksi Tanaman Kacang Tanah}

Hasil sidik ragam menunjukan bahwa pupuk kompos daun jagung tidak berpengaruh nyata terhadap rata-rata tinggi tanaman umur 30, 60, 90 hari setelah tanam, rata-rata berat polong dan jumlah polong. Diduga hal ini karena tanaman masih belum dapat menyesuaikan dengan keadaan lingkungan dan pupuk yang diberikan belum dapat dimanfaatkan secara maksimal untuk meningkatkan pertumbuhan vegetatif tanaman. Hasil uji laboratorium kompos daun jagung memiliki kadar C-organik 27,99\%, N-total $2,66 \%, \mathrm{C} / \mathrm{N}$ rasio $11, \mathrm{P}_{2} \mathrm{O}_{5} 4,64 \%$, dan $\mathrm{K}_{2} \mathrm{O}$ $3,98 \%$. Dari hasil yang didapat menunjukan bahwa kandungan pupuk kompos daun jagung memiliki kandungan unsur hara yang sangat kecil, hal ini menyebabkan unsur hara yang tersedia ditanah juga kurang sehingga berakibat pada rendahnya pertumbuhan dan hasil kacang tanah. Menurut pendapat Harjadi (2003), tanaman perlu beradaptasi dalam menyerap unsur hara setelah dipindahkan dari tanah yang berbeda. Ditambahkan oleh Sutedjo (2008), pertumbuhan tidak akan berpengaruh terhadap perkembangan daun, batang, dan akar apabila pupuk yang diberikan belum diserap seluruhnya oleh tanaman. Hal ini menunjukan bahwa yang terdapat dalam tubuh tanaman sangat berhubungan dengan pertumbuhannya.

Pertumbuhan tanaman yang baik ditandai dengan tersedianya kadar unsur hara yang terkandung didalam tanah. Menurut Lingga dan Marsono (2010), bahwa konsentrasi pupuk merupakan faktor yang sangat vital dan memiliki pengaruh yang sangat besar terhadap keberhasilan, oleh karena itu untuk mendapatkan pertumbuhan dan hasil yang optimal harus memperhatikan dosis dan konsentrasi pemupukan yang tepat.

Perlakuan tanpa pupuk $\mathrm{O}_{0}$ (tanpa pupuk/control), menunjukan hasil yang terendah karena kurangnya unsur yang tersedia sehingga peryumbuhan tanaman menjadi rendah. Menurut Jumin (2002), apabila jumlah unsur hara makro dan mikro yag tersedia sedikit, maka hara yang diserap tanaman akan kurang hal ini berakiba $\mathrm{t}$ pada proses fotosintesis yang sedikit dalam menghasilkan nutrisi dan berdampak pada rendahnya pertumbuhan vegetatif.

\section{Pengaruh Pemberian Pupuk NPK Phonska Terhadap Produksi Tanaman Kacang Tanah}

Hasil sidik ragam menunjukan bahwa pupuk NPK Phonska tidak berpengaruh nyata terhadap rata-rata tinggi tanaman umur 30, 60, dan 90 hari setelah tanam tetapi berpengaruh nyata terhadap rata-rata berat polong dan jumlah polong. Pemupukan adalah salah satu metode perlakuan yang diberikan pada tanaman dengan tujuan untuk meningkatkan pertumbuhan dan perkebangan tanaman, tetapi apabila tanaman tidak merespon pupuk yang di berikan, hal ini diduga dosis yang kurang mencukupi kebutuhan tanaman. Menurut Harjadi (2003), pemberian pupuk merupakan faktor utama yang sangat penting dalam pemupukan. Pemupukan yang efektif harus diberikan ditempat dan disaat tanaman memerlukan. Ditambahkan oleh Novizan (2002), pupuk nitrogen $(\mathrm{N})$, fosfor $(\mathrm{P})$ dan kalium (K), dapat meningkatkan pertumbuhan dan produktivitas tanaman selain itu bahwa pemberian pupuk merupakan faktor utama yang sangat penting dalam pemupukan, agar efektif pupuk harus diberikan ditempat dan disaat tanaman memerlukan.

Pemberian pupuk NPK Phonska berpengaruh nyata terhadap rata-rata berat polong dan jumlah polong. Secara umum unsur $\mathrm{K}$ berperan dalam pembentukan umbi dan dapat meningkatkan aktifitas fotosintesis dan kandungan klorofil daun sehingga dapat meningkatkan bobot kering tanaman. Menurut Damanik, dkk (2010) kalium (K) sangat dibutuhkan untuk proses fotosintesis serta dapat meningkatkan berat umbi.

\section{Pengaruh Interaksi Pemberian Pupuk Kompos Daun Jagung dan Pemberian Pupuk NPK Phonska}

Hasil analisis ragam dapat diketahui bahwa interaksi antara pemberian pupuk kompos daun jagung dan pupu NPK phonska tidak berpengaruh nyata terhadap semua parameter penelitian sesuai pendapat Steel dan Torrie (1993), bahwa apabila antara dua faktor tidak berpengaruh nyata maka dapat disimpulkan bahwa faktor-faktor tersebut bertindak bebas satu dengan lainnya. 


\section{KESIMPULAN}

1. Pemberian pupuk kompos daun jagung tidak berpengaruh nyata terhadap rata-rata tinggi tanaman umur 30, 60, 90 hari setelah tanam, berat polong dan jumlah polong.

2. Pemberian pupuk NPK Phonska berpengaruh nyata terhadap rata-rata berat polong dan jumlah polong namun tidak berpengaruh nyata terhadap rata-rata tinggi tanaman umur 30, 60, 90 hari setelah tanam. Perlakuan yang terbaik di capai oleh dosis $15 \mathrm{~g} / \operatorname{tanaman}\left(\mathrm{K}_{3}\right)$.

3. Interaksi antara kedua pupuk kompos daun jagung dan pupuk NPK Phonksa tidak berpengaruh nyata terhadap semua parameter.

\section{DAFTAR PUSTAKA}

Adisarwanto, T. 2009. Meningkatkan Produksi Kacang Tanah Di Lahan Sawah Dan Lahan Kering, PT. Penebar Swadaya. Jakarta.

Buckman, H,O. dan N,C. Brady, 1993. The Nature and Properties of Soil. Terjemahan Soegiman. Ilmu Tanah. Bhatara Karya Aksara. Jakarta.

Cahyono, B., 2007. Budidaya Kacang Tanah. Aneka Ilmu, semarang.

Damanik, M. M. B., B. E. Hasibuan, Fauzi, Sarifuddin, H. Hanum., 2010. Kesuburan Tanah dan Pemupukan. USU Press. Medan.

Fitter AH, Hay RK. 1991. Fisiologi Lingkungan Tanaman. Yogyakarata (ID): Gajahmada University Press.

Hanafah, K.A. 2005. Rancangan Percobaan. PT. Raja Grafindo. Jakarta.

Harjadi, S.S. 2003. Pengantar Agronomi. Wiramedia Pustaka Utama, Jakarta.

Indranada, H, K, 1994. Penggolongan Kesuburan Tanah. Bina Aksara. Jakarta.

Jumin, H.B. 2002. Rancangan Percobaan: Teori dan Aplikasi. Raja Grafindo Persada, Jakarta.
Lingga, P dan Marsono, 2010. Petunjuk Penggunaan Pupuk. Penebar Swadaya. Jakarta.

Marzuki, H.A.R., 2007. Bertanam Kacang Tanah. Penebar Swadaya. Jakarta.

Murbandono. 2006. Membuat Kompos. Edisi revisi. Penebar Swadaya, Jakarta.

Novizan 2002. Petunjuk Pemupukan Yang Efektif. Agro Media Pustaka, Jakarta.

Osman. F. 1996. Memupuk Padi dan Palawija. Penebar Swadaya. Jakarta.

Pitojo, s., 2005. Benih Kacang Tanah. Kanisius, Yogyakarta.

Purbayanti, Lukiwati dan Trimulatsih. 1995. Dasar Dasar Ilmu Tanah. terjemahan dari Fundamentals of Soil Science. Yogyakarta (ID): Gadjah Mada University Press.

Rismunandar, 1993. Tanah dan Seluk Beluknya Bagi Pertanian. Sinar Baru Algsindo,

Bandung.

Rubatzky, V.E dan Yamaguchi, M, 1995. World vegetable, Principles, Production. Gizi ITB, Bandung.

Rukmana. 2010. Prospek Jagung Manis. Pustaka Baru Press. Yogyakarta.

Steel, R. G. D. And Torrie, J. H. 1993. Principles and procedur of statistic (Terjemahan Bambang Sumantri, Prinsip dan prosedur statistika). Gramedia, Jakarta.

Sugeng, H.R, 1992. Bercocok Tanam Sayuran. Aneka Ilmu. Semarang.

Sutedjo. M.M, 1995. Pupuk dan Cara Pemupukan. Rineka Cipta. Jakarta.

Sutedjo.M. M, 2008. Pupuk Dan Cara Pemupukan. Bhineka Cipta, Jakarta.

Sutrisno. 2004. Studi Dosis Pupuk dan Jarak Tanam Kacang Tanah (Arachis hypogaea, L.). Pati (ID): Kantor Litbang Kabupaten Pati. 